\title{
Altered Cellular Distribution of Tuberin and Glucocorticoid Receptor in Sporadic Fundic Gland Polyps
}

Jianjun Wei, M.D., Luis Chiriboga, Ph.D., Herman Yee, Ph.D., M.D., Masashi Mizuguchi, Ph.D., M.D., Eric Li, M.D., Gurdip S. Sidhu, M.D., A. Brian West, M.D.

Department of Pathology, New York University School of Medicine (JW, LC, HY, EL, BW), New York, New York; Veterans Affairs Medical Center (GSS), New York, New York; and Department of Pediatrics, Jichi Medical School (MM), Minamikawachi, Kawachi-gun, Tochigi, Japan

Gastric fundic gland polyps (FGPs) are considered hamartomas, and various gastrointestinal hamartomas are associated with tuberous sclerosis complex (TSC). The aim of this study was to investigate a possible link between TSC proteins (hamartin and tuberin) and sporadic FGPs. We examined 33 sporadic FGPs and 26 biopsies of normal fundic mucosa by immunohistochemistry. Nuclear immunoreactivity for tuberin was dramatically reduced or lost in most sporadic FGPs, and tuberin unexpectedly accumulated in the cytoplasm in oxyntic glands. About 18\% (6/33) of FGPs were immunopositive in an average of $1.7 \%$ of oxyntic cell nuclei, compared with $77 \%(20 / 26)$ of controls in an average of $24.4 \%$ of oxyntic cell nuclei $(P<.01)$. No change in hamartin was noted. We further examined the tuberin-associated proteins glucocorticoid receptor (GCR) and p27. Nuclear immunoreactivity for GCR was lost in most sporadic FGPs, but p27 distribution was normal. Sporadic FGPs had a low frequency of staining for Ki-67 except for some cells from cystic components, which is consistent with their slow growth. Our results are consistent with the hypothesis that tuberin may play an important role in pathogenesis of sporadic FGPs. First, an altered cellular localization of tuberin may lead to the deregulation of cell proliferation by interrupting its interaction with hamartin. Second, altered cellular localization of tuberin may preclude its negative regulation of gene transcription mediated by GCR.

Copyright () 2002 by The United States and Canadian Academy of Pathology, Inc.

VOL. 15, NO. 8, P. 862, 2002 Printed in the U.S.A.

Date of acceptance: May 6, 2002.

Address reprint requests to: A. Brian West, M.D., New York University,

Department of Pathology, 560 First Avenue, Tisch 461, New York, NY

10016; e-mail: brian.west@med.nyu.edu; fax: 212-263-7916.

DOI: 10.1097/01.MP.0000024146.29531.5B
KEY WORDS: Fundic gland polyp, Glucocorticoid receptor, Hamartin, Tuberin.

Mod Pathol 2002;15(8):862-869

Fundic gland polyps (FGPs) are sessile polyps of gastric mucosa that are often multiple. Histologically, FGPs are formed of cystically dilated, irregularly deformed oxyntic glands with or without glandular proliferation, increased smooth muscle in the lamina propria, and an absence of proliferation of the foveolar epithelium. The nature of FGPs is still debated: most have considered them to be hamartomatous lesions (1), others as a peculiar form of hyperplastic polyp (2). FGPs present both in a sporadic form and in a syndromic form. The latter is associated with familial adenomatous polyposis (3).

The sporadic form of FGP is the most common gastric polyp (4) and occurs with a mean age in the 6 th decade and male-female ratio of 1:4-5 $(5,6)$. Most sporadic FGPs remain unchanged for a long period of time (7). FGPs arise in acid-secreting areas of the gastric mucosa and secrete acid (8). Gastrin does not appear to play a role in the development of sporadic FGPs (9). Because the prevalence of Helicobacter pylori infection is lower in patients with FGPs than in control individuals and patients with hyperplastic polyps, $H$. pylori has been excluded as a cause of FGPs (10). Proton pump inhibitors (PPIs) such as Omeprazole have been reported to be associated with the genesis of FGPs (11), but this was not supported by a large retrospective study (12), and PPI-associated fundic gland cysts lack superficial (foveolar) dilations, a hallmark of FGPs $(13,14)$. A recent study showed that most sporadic FGPs had activating $\beta$-catenin gene mutations (15). $\beta$-Catenin functions as a submembranous component in cadherin-mediated cell-cell adhesion (16). Mutation of the $\beta$-catenin gene is common in gastric and colon cancers, characteristically resulting in nuclear translocation of the pro- 
tein (17-19). Nuclear translocation of mutant $\beta$-catenin is not present in sporadic FGPs (15).

Tuberin (TSC2) and hamartin (TSC1) are tumor suppressors. Mutations of either gene result in the tuberous sclerosis complex (TSC) and multiple organ hamartomas (20-22), including gastrointestinal polyps (23-26). Tuberin and hamartin negatively regulate the proliferation/cell cycle in cells that express the genes. Regulation of hamartin and tuberin remains unknown. It has been reported that tuberin interacts and colocalizes with CDK1, cyclin B1 (27), p27 (28, 29), and glucocorticoid receptor (GCR; 30). Hamartin regulates cell-cell adhesion mediated by the ezrin-radixin-moesin (ERM) proteins and the GTPase Rho (31). The association between hamartin and $\beta$-catenin in the regulation of cellcell adhesion is not known. Because hamartin, tuberin, GCR, and p27 are expressed in normal gastric mucosa (32-35), the expression pattern of these proteins in sporadic FGPs is of interest, although no typical FGPs are reported in TSC. The aim of this study is to investigate the localization of hamartin, tuberin, GCR, and p27 in sporadic FGPs, using normal fundic mucosa for comparison. The findings shed light on the pathogenesis of sporadic FGPs as well as that of hamartomas generally.

\section{MATERIALS AND METHODS}

\section{Clinical Materials}

Archival formalin-fixed, paräffin-embedded biopsy specimens of sporadic FGPs were collected from 33 patients who underwent upper gastrointestinal endoscopy at the New York University Hospitals Center between 2000 and 2001. The age range in this group was 20 to 82 years (mean age, $62.9 \mathrm{y}$ ), with 22 females and 11 males. Twenty-six biopsies of normal gastric oxyntic mucosa were used as controls. The age range of control patients was 23 to 77 years (mean age: 59.3 y), with 13 females and 12 males.

\section{Antibodies}

\section{Hamartin}

Antibodies to hamartin were raised in rabbits against two peptides synthesized according to the sequence deduced from human TSC1 cDNA. These peptides consisted of hamartin amino acid residues 231-245 plus the carboxy-terminal cysteine (peptide Ham-T2: PELVTGSKDHELDPRC), and residues 1150-1164 plus the amino-terminal cysteine (peptide Ham-CT: CQLHIMDYNETHHEHS). The characteristics of these antibodies have been previously reported (36-38).

\section{Tuberin}

Antibody to tuberin was raised in rabbits against a peptide synthesized according to the sequence deduced from human TSC2 cDNA. It consisted of amino acid residues 1770 to 1784 plus the aminoterminal cysteine (peptide Tub-CT: CRKRLISSVEDFTEFV), corresponding to the carboxy terminal of tuberin. The characteristics of this antibody have previously been reported (36-38).

\section{P27, GCR, and Ki-67}

Mouse monoclonal antihuman antibodies were obtained commercially from DAKO (p27; Carpinteria, CA), Novocastra (GCR; Newcastle upon Tyne, UK), and Ventana (Ki-67; Tucson, AZ).

\section{Immunohistochemistry}

Four-micrometer tissue sections were deparaffinized in the usual manner followed by heatinduced epitope retrieval ( $15 \mathrm{~min})$ in $0.01 \mathrm{~m}$ citric acid buffer ( $\mathrm{pH}$ 6.0). Antibodies were used at concentrations of 1:350 Ham-T2, 1:800 Ham-CT, and 1:1000 Tub-CT; and in the case of p27, GCR, and $\mathrm{Ki}-67$, as recommended by the manufacturers. All immunoperoxidase staining was performed on a Nexes immunostainer (Ventana). Endogenous peroxidase activity was blocked with $3 \%$ hydrogen peroxide. Primary antibodies were detected using standard biotinylated anti-mouse or anti-rabbit secondary antibodies. The complex was visualized by the enzymatic reduction of 3,3' diaminobenzidine tetrahydrochloride substrate and enhanced with copper sulfate. To minimize technique bias, the following steps were taken: (1) to ensure uniform treatment of individual specimens, sections of five to seven FGPs were put on the same slide for staining; (2) experiments were repeated to confirm reproducibility; and (3) cytoplasmic counterstaining with fast blue was used to visualize nuclear immunoreactivity, whereas nuclear counterstaining with hematoxylin was used when evaluating cytoplasmic immunoreactivity.

\section{Scoring and Statistical Analysis}

In each stained section, the numbers of positively and negatively stained cells were counted in profiles of 100 glands, and the results were recorded in deciles. The glands selected for counting were in the upper half of the subfoveolar mucosa, where polyp glands are readily recognized by their distortion and loss of polarity. The immunoreactivity for hamartin, tuberin, GCR, and p27 were scored. Different subcellular locations were evaluated separately for each antibody. Immunostaining intensity was recorded as negative $(0)$, low $(+)$, moderate $(++)$, and high $(+++)$. 


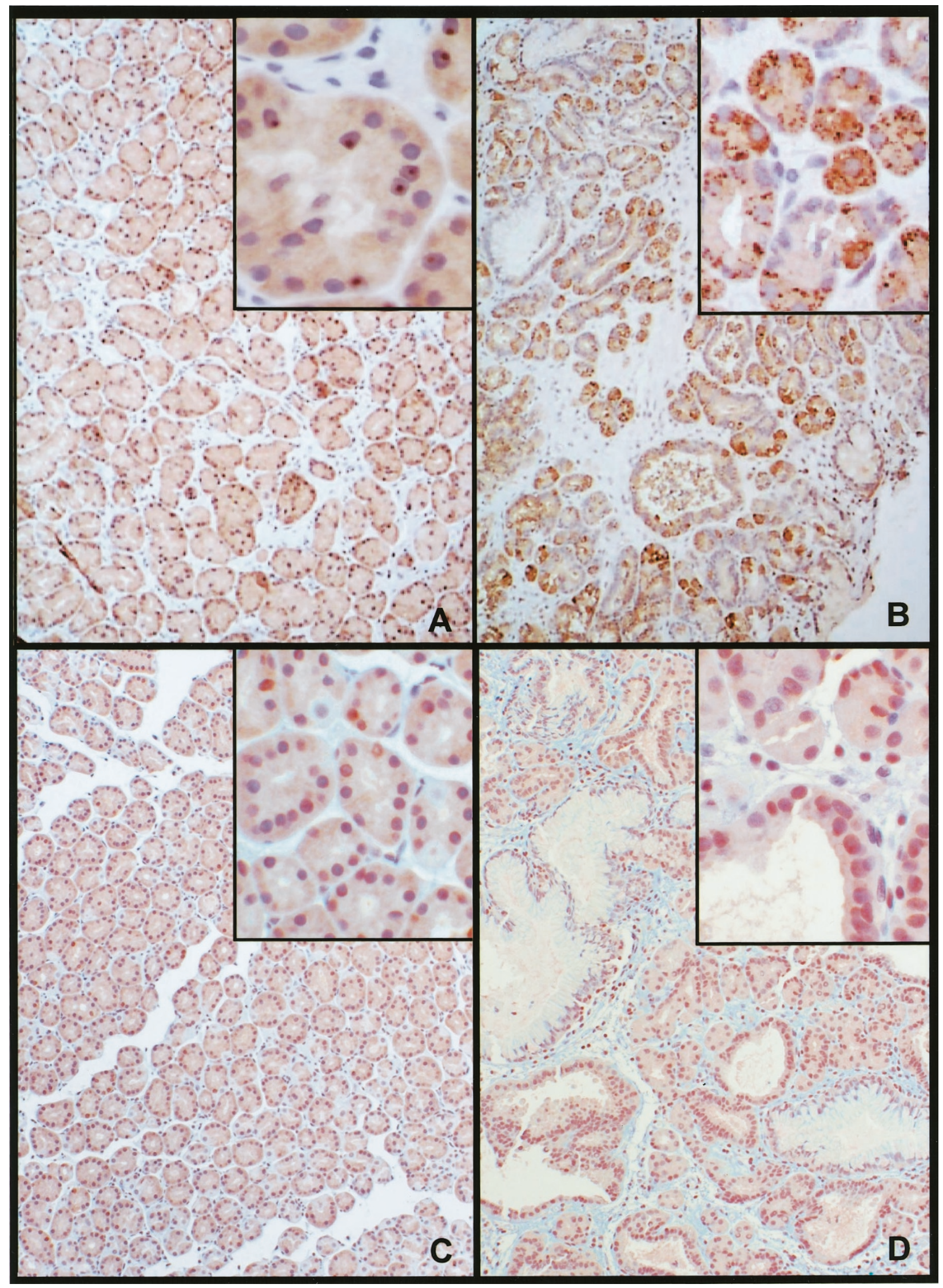

FIGURE 1. Immunohistochemical staining of normal oxyntic mucosa and fundic gland polyps (FGPs) for tuberin (A and $\mathbf{B})$ and hamartin (C and D). Tuberin is normally expressed both in the nucleus and the cytoplasm in normal mucosa (A). In FGPs, tuberin is present only in the cytoplasm (B) and accumulates in large coarse granules in the parietal cells $(\mathbf{B}$, inset). Nuclear and cytoplasmic immunostaining for hamartin is positive in both normal mucosa and FGPs (C and $\mathbf{D})$. 
TABLE 1. Tuberin, GCR, and p27 Immunostaining in Oxyntic Cells of FGPs and Normal Controls

\begin{tabular}{|c|c|c|c|}
\hline \multirow[b]{2}{*}{ Immunostain } & \multicolumn{3}{|c|}{ Mean Percentage of Stained Cells } \\
\hline & $\begin{array}{l}\text { Normal Mucosa } \\
\quad(n=26)\end{array}$ & $\begin{array}{c}\text { FGPs } \\
(n=33)\end{array}$ & $P$ \\
\hline \multicolumn{4}{|l|}{ Tuberin } \\
\hline Nuclear & $24.40 \pm 25.27$ & $1.70 \pm 5.54$ & $<0.001$ \\
\hline Cytoplasmic $^{a}$ & $6.15 \pm 10.03$ & $26.53 \pm 23.77$ & $<0.001$ \\
\hline \multicolumn{4}{|l|}{ GCR } \\
\hline Nuclear & $43.00 \pm 34.20$ & $6.43 \pm 12.30$ & $<0.001$ \\
\hline \multicolumn{4}{|l|}{ p27 } \\
\hline Nuclear & $61.90 \pm 26.05$ & $73.80 \pm 21.90$ & $>0.05$ \\
\hline Cytoplasmic $^{b}$ & 0.0 & 0.0 & \\
\hline $\begin{array}{l}\text { GCR, glucocor } \\
{ }^{a} \text { Cytoplasmic } \\
{ }^{b} \text { Data from } 2 \\
\text { aining in near } 9\end{array}$ & $\begin{array}{l}\text { ceptor; FGP, fun } \\
\text { granule immun } \\
\text {. Two FGPs sho } \\
\text { cells. }\end{array}$ & $\begin{array}{l}\text { nd polyp. } \\
\text { ng. } \\
27 \text { cytoplas }\end{array}$ & \\
\hline
\end{tabular}

The mean and standard deviation of percentage positivity and intensity were calculated for all the antibodies. A $P$ value of $<.05$ was considered significant for the difference between sporadic FGPs and normal controls.

\section{RESULTS}

Pathological Evaluation of FGPs

All FGPs contained fundic gland cysts with superficial (foveolar) epithelium as part of the cystic component. The cysts comprised 10 to $80 \%$ of the sectioned area of polyps. Oxyntic glandular proliferation, smooth muscle proliferation, and increased stroma were seen in most cases. No dysplasia was present in this group. FGPs ranged in size from 2 to $12 \mathrm{~mm}$.

\section{Tuberin}

In normal fundic mucosa, there was weak to moderate cytoplasmic immunoreactivity for tuberin in both parietal and chief cells, with greater staining intensity in the basal cytoplasm. Foveolar epithelium did not stain. Many oxyntic glands showed moderate immunoreactivity in the nucleus, mostly confined to parietal cells (Fig. 1A-B). Among 26 control cases, $77 \%$ showed nuclear immunopositivity, with an overall mean of $24.4 \%$ positive cells in the oxyntic glands (Table 1). In many cells, there was a densely stained intranuclear globule suggestive of a nucleolus (Fig. 1A, inset).

In FGPs, immunostaining for tuberin was dramatically reduced or lost in the nuclei. Among 33 FGPs, only $18 \%$ had stained oxyntic cell nuclei, and in these the average percentage of immunopositive nuclei was only $1.7 \%$ (Fig. 2A; Table 1). Nuclear immunoreactivity, where present, was characterized by markedly decreased staining intensity. Cytoplasmic immunoreactivity for tuberin was in the

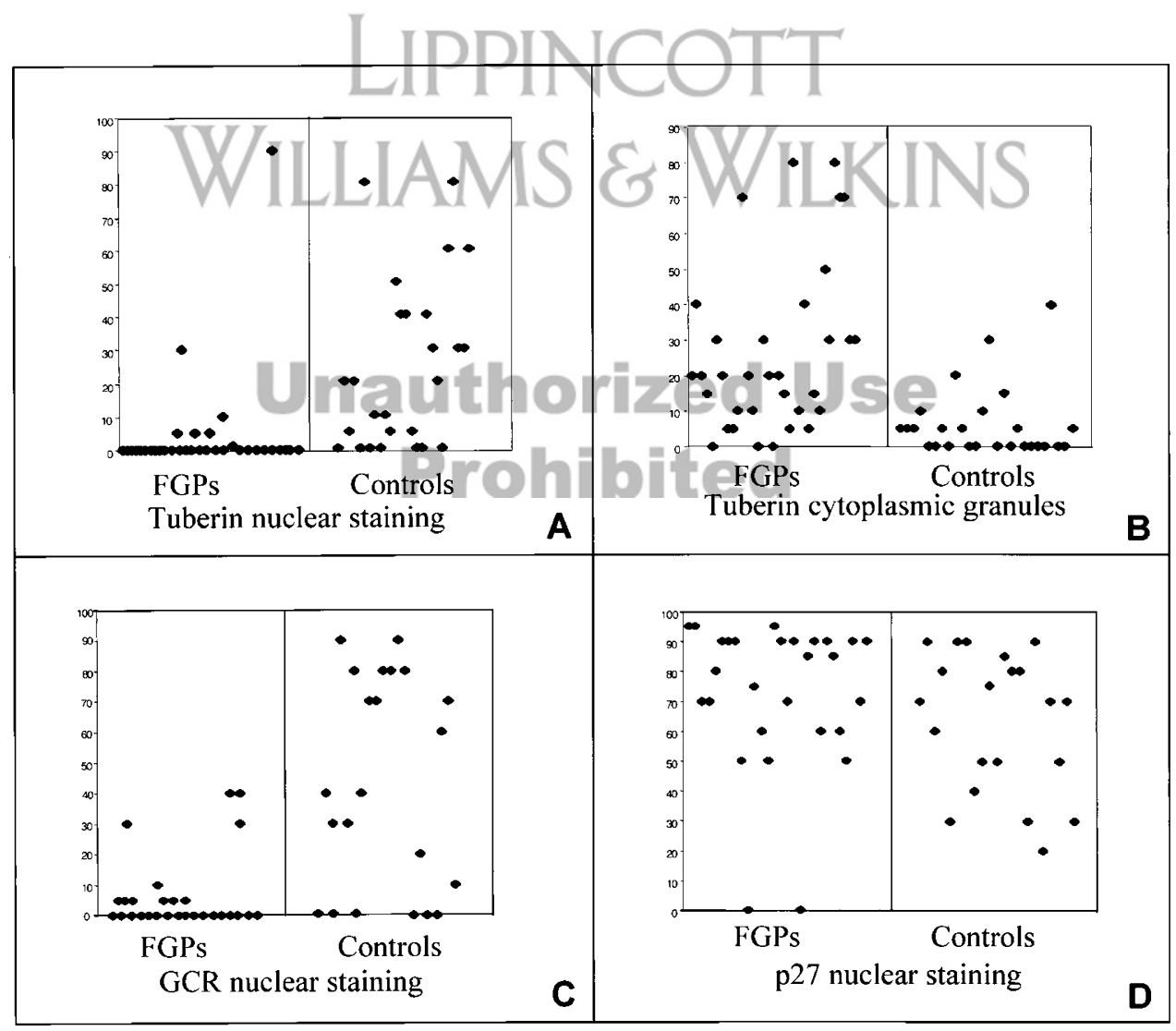

FIGURE 2. Percentage of oxyntic cells that are immunopositive for tuberin, glucocorticoid receptor (GCR), and p27 in normal controls and fundic gland polyps. Each dot represents one case. A, nuclear immunostaining for tuberin; B, immunostaining of cytoplasmic coarse granule for tuberin; C, nuclear immunostaining for GCR; and D, nuclear immunostaining for p27. 


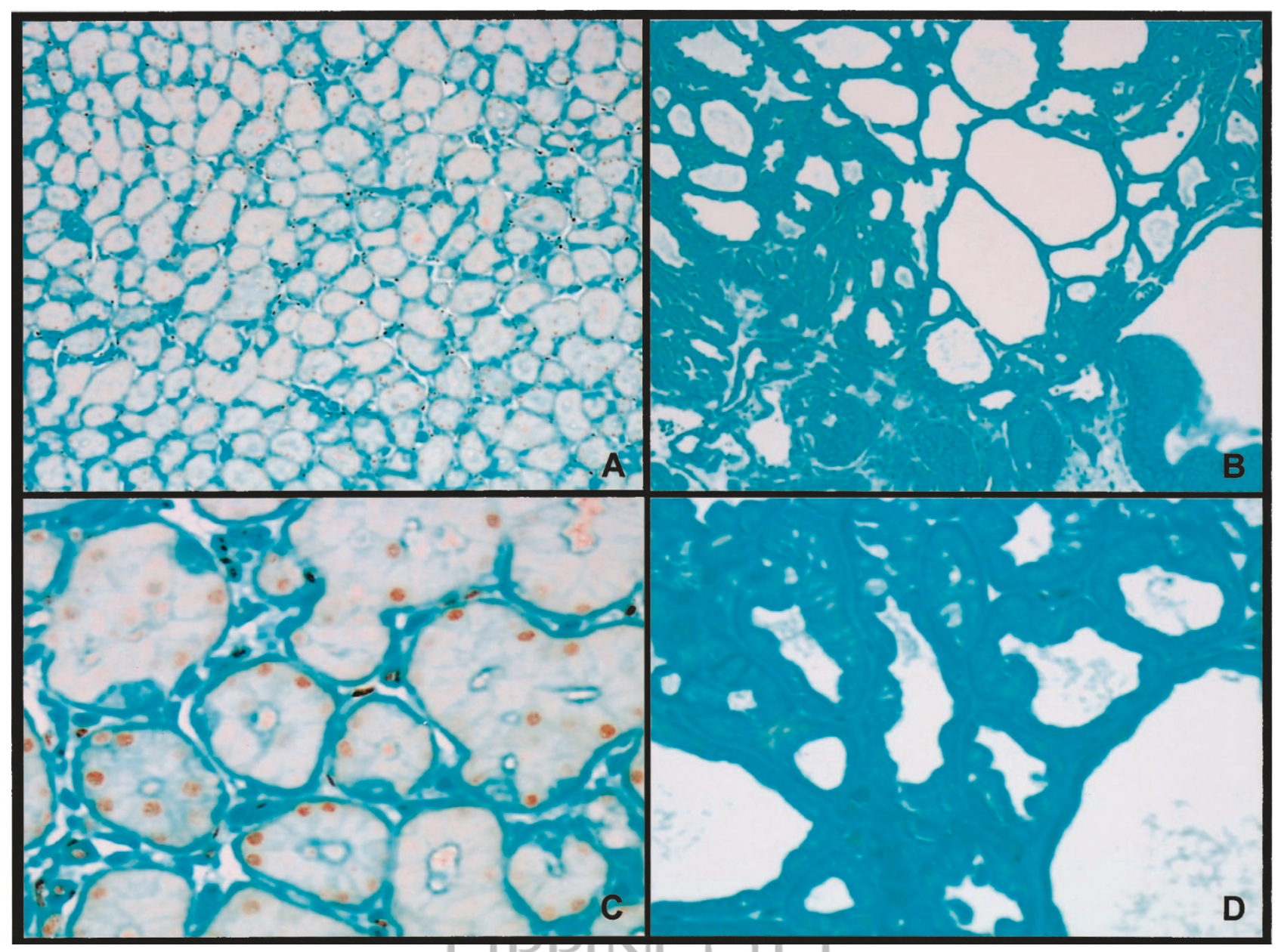

FIGURE 3. Immunohistochemical staining of normal oxyntic mucosa and fundic gland polyps (FGPs) for glucocorticoid receptor (GCR). In normal oxyntic glands, immunoreactivity for GCR is seen in the nucleus (A, C). There is virtually no immunopositivity for GCR in the sporadic FGPs (B, D). (Diaminobenzidine with fast blue cytoplasmic counterstain.)

form of large coarse granules, which were only rarely seen in normal fundic glands. This accumulation of tuberin was more prominent in parietal cells of the deformed glands (Fig. 1B). Immunoreactivity for tuberin remained negative in foveolar epithelium. The immunoreactivity for tuberin in nonepithelial cells, such as smooth muscle, endothelium, and plasma cells, was weak and similar in the two groups.

\section{Hamartin}

Hamartin was weakly to moderately expressed in both nucleus and cytoplasm of oxyntic glands but not in foveolae. Immunostaining with the antibodies to $\mathrm{N}$ and $\mathrm{C}$ terminals of hamartin showed the same pattern in the controls and the FGPs, although a slight reduction of immunoreactivity was seen in the latter. No coarse granular staining was seen (Fig. 1C-D).

\section{Glucocorticoid Receptor}

As previously reported (32), immunoreactivity for GCR was seen in the neck, isthmus, and basal por- tions of normal fundic glands, but not in foveolae. Of 21 control cases, $71 \%$ showed nuclear staining for GCR in oxyntic glands with a mean positivity of $43.0 \%$ of oxyntic cells (Fig. 2C). FGPs showed partial or complete loss of nuclear staining. Of 28 FGPs, only $18 \%$ stained positive, with a mean of $6.43 \%$ of oxyntic cell nuclei staining (Table 1). The nuclear staining intensity was much weaker than in the controls. No cytoplasmic immunoreactivity was noted in either group (Fig. 3). Plasma cells, which show nuclear immunopositivity for GCR, served as internal controls.

\section{p27}

p27 was detected in nuclei of oxyntic and foveolar epithelium in normal controls and FGPs. There was no significant difference in the number of positive cells (Fig. 2D; Table 1). However, two FGPs showed complete loss of nuclear immunoreactivity. In these two FGPs, immunoreactivity was misplaced from the nucleus to the cytoplasm. 


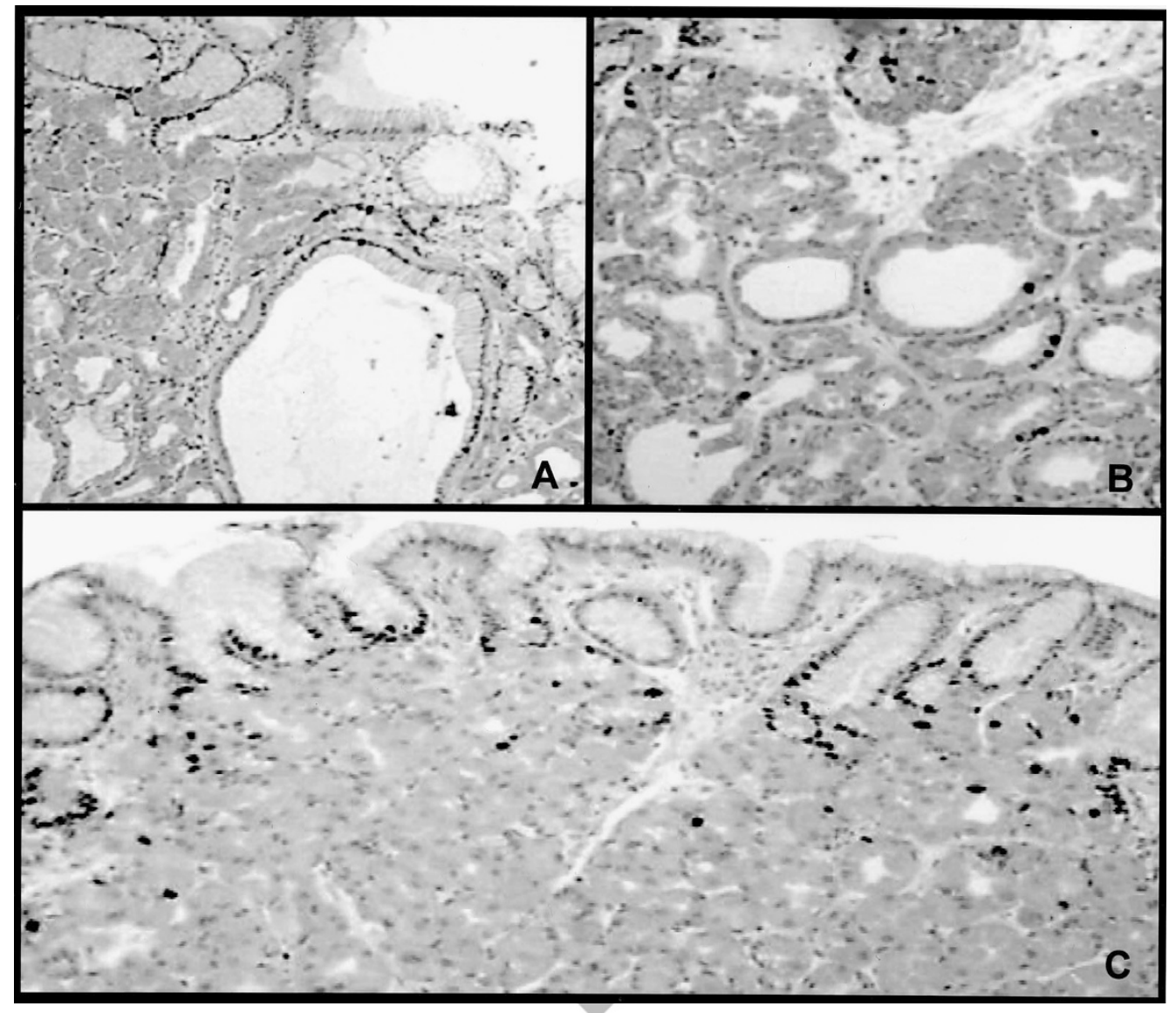

FIGURE 4. Immunohistochemical staining of normal oxyntic mucosa and fundic gland polyps (FGPs) for Ki-67. Immunoreactivity for Ki-67 is mostly seen in cells of the fundic neck in both normal oxyntic mucosa (C) and FGPs (A and B). Cysts of FGPs show an increase of immunopositivity for Ki-67 (A and B).

\section{Ki-67}

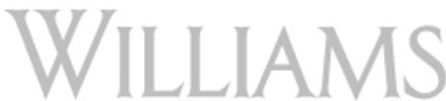

Immunoreactivity for Ki-67 was examined in 28 sporadic FGPs and 21 controls. Both groups showed similar numbers and location of immunopositive cells. Ki-67 staining was seen in epithelial cells in the neck of fundic glands between the foveolae and the oxyntic cells. Parietal and chief cells were rarely positive. There was a slight increase in immunopositive cells in the cystic components in FGPs, consistent with the presence of neck cells (Fig. 4).

\section{DISCUSSION}

Tuberin and hamartin are multifunctional proteins associated with cell adhesion (31), cell cycle/ proliferation $(27,28)$, and transcriptional signaling (30). Hamartin and tuberin may function in different cellular locations. In our previous study with pediatric tissues, we found that hamartin and tuberin were indeed expressed in different subcellular regions in different tissues or cells (35). The significance of the different cellular localization of hamartin and tuberin is not known. Because these proteins have been shown to interact stably in vitro and in vivo (39-43), they might function together in vivo. Experiments in Drosophila $(44,45)$ demonstrated that the presence of both proteins in cells was necessary in controlling tissue mass. Our data (35) suggest that loss of either protein from tissues in which normally both are present is associated with a high incidence of hamartoma formation in early childhood. Therefore, interruption of the protein- protein interaction between hamartin and tuberin, such as altered localization of one of the proteins, may interrupt their normal function.

Hamartin and tuberin are normally expressed in both the cytoplasm and the nucleus of gastric oxyntic cells. No change in the distribution of hamartin was seen in FGPs, although the intensity of immunostaining was decreased in comparison with controls. In contrast, most FGPs lost their nuclear immunoreactivity for tuberin, and the protein accumulated in the cytoplasm in the form of large coarse granules. Nuclear immunoreactivity for GCR also was lost in most FGPs, but without cytoplasmic accumulation (Table 1).

Tuberin contains a domain that tightly interacts with steroid receptor families, especially with GCR, to form a complex $(46,47)$. This complex is a strong negative regulator of the transcriptional activity of 
GCR (30). GCR is known to be an important factor influencing gastric mucosal function and morphology $(32,48)$. GCR binding to its ligands promotes an increase of hydrochloric acid and pepsin secretion. Loss of tuberin from the nucleus in FGPs precludes its negative control of transcription by GCR, theoretically resulting in up-regulation of acid secretion. Consistent with this, FGPs are well endowed with parietal cells and have been observed by chromoendoscopy to secrete acid in vivo (8). However, we found that GCR, also, was lost from the nuclei of FGP oxyntic cells. Given the fact that GCR tightly interacts with tuberin, one of GCR's roles may be as a carrier protein to bring tuberin into the nucleus in normal oxyntic glands. Therefore, down-regulation of GCR expression in FGPs may block transportation of tuberin into the nucleus and lead to tuberin accumulation in the cytoplasm. Furthermore, the abnormal accumulation of tuberin in the cytoplasm may impair its interaction with other proteins (like hamartin) in specific subcellular compartments and deregulate cell proliferation.

The finding of activating $\beta$-catenin mutations in sporadic FGPs provides evidence of the molecular defect that may, by means not yet known, directly or indirectly induce the lesion (15). The mutation of $\beta$-catenin in sporadic FGPs is associated with a benign proliferation. Interestingly, mutant $\beta$-catenin does not translocate to the nucleus in FGPs, as occurs in $\beta$-catenin-associated malignant tumors of the gastrointestinal tract. The latter may require nuclear translocation of the mutated $\beta$-catenin to activate the Wnt signaling pathway (17-19). Alteration/of tuberin rarely, if ever, induces malignancy. Rather, it induces benign tumorigenesis by loss of control of cell proliferation and cell-cell interaction. It would be interesting to know whether tuberin blocks $\beta$-catenin translocation or whether mutant $\beta$-catenin promotes the accumulation of tuberin in the cytoplasm. So far, there is no experimental evidence to link $\beta$-catenin and tuberin. The pathogenic relationship of these two proteins needs further study.

p27 has been reported to be functionally associated with tuberin $(28,29)$. The absence of the latter in vitro results in p27 instability and cytoplasmic accumulation. In this regard, we examined the expression of p27 in sporadic FGPs. Although sporadic FGPs showed abnormal accumulation of tuberin in the cytoplasm rather than loss of tuberin, absence of p27 from the nucleus and its accumulation in the cytoplasm was seen in only two FGPs. Therefore, the role of $\mathrm{p} 27$ in sporadic FGPs appears not to be important in most instances. FGPs remain unchanged for very long periods (7). Thus, a slightly higher incidence of Ki-67 in sporadic FGPs, indicative of a small increase in the rate of cell proliferation, could over time account for the increased cell mass in these lesions.
In conclusion, we found altered cellular localization of tuberin in the cytoplasm in most sporadic FGPs. Loss of tuberin from the nucleus is associated with down-regulation of GCR. However, the accumulation of tuberin in the cytoplasm seems not to affect the nuclear distribution of p27 in most cases. We speculate that altered localization of tuberin may block nuclear translocation of mutant $\beta$-catenin, leading to a benign cellular proliferation rather than a malignant transformation.

\section{REFERENCES}

1. Odze RD. Gastric fundic gland polyps: are they preneoplastic lesions? Gastroenterology 1998;114:422-3.

2. Declich P, Ambrosiani L, Grassini R, Tavani E, Bellone S, Bortoli A, et al. Fundic gland polyps: a still elusive entity on the eve of the year 2000 [review]. Pol J Pathol 2000;51:3-8.

3. Iida M, Yao T, Itoh $\mathrm{H}$, Watanabe $\mathrm{H}$, Kohrogi $\mathrm{N}$, Shigematsu A, et al. Natural history of fundic gland polyposis in patients with familial adenomatosis coli/Gardner's syndrome. Gastroenterology 1985;89:1021-5.

4. Stolte M, Sticht T, Eidt S, Ebert D, Finkenzeller G. Frequency, location, and age and sex distribution of various types of gastric polyp. Endoscopy 1994;26:659-65.

5. Iida $M$, Yao $T$, Watanabe $H$, Itoh $H$, Iwashita $A$. Fundic gland polyposis in patients without familial adenomatosis coli: its incidence and clinical features. Gastroenterology 1984;86: 1437-42.

6. Marcial MA, Villafana M, Hernandez-Denton J, Colon-Pagan JR. Fundic gland polyps: prevalence and clinicopathologic features. Am J Gastroenterol 1993;88:1711-3.

7. Hizawa K, Iida M, Matsumoto T, Aoyagi K, Yao T, Fujishima M. Natural history of fundic gland polyposis without familial adenomatosis coli: follow-up observations in 31 patients. Radiology 1993;189:429-32.

8. Iishi H, Tatsuta M, Okuda S. Clinicopathological features and natural history of gastric hamartomatous polyps. Dig Dis Sci 1989;34:890-4.

9. Haruma K, Sumii K, Yoshihara M, Watanabe C, Kajiyama G. Gastric mucosa in female patients with fundic glandular polyps. J Clin Gastroenterol 1991;13:565-9.

10. Sakai N, Tatsuta M, Hirasawa R, Iishi H, Baba M, Yokota Y, et al. Low prevalence of Helicobacter pylori infection in patients with hamartomatous fundic polyps. Dig Dis Sci 1998; 43:766-72.

11. El-Zimaity HM, Jackson FW, Graham DY. Fundic gland polyps developing during omeprazole therapy. Am J Gastroenterol 1997;92:1858-60.

12. Vieth M, Stolte M. Fundic gland polyps are not induced by proton pump inhibitor therapy. Am J Clin Pathol 2001;116: 716-20.

13. Riddell RH. The biopsy diagnosis of gastroesophageal reflux disease, "carditis," and Barrett's esophagus, and sequelae of therapy [review]. Am J Surg Pathol 1996;20(Suppl 1):S31-50.

14. Declich P, Bellone S, Porcellati M, Bortoli A, Gozzini C, Tavani E, et al. Parietal cell protrusions with fundic gland cysts and fundic gland polyps: are they related or simply similar but distinguishable? Hum Pathol 2000;31:1536-7.

15. Abraham SC, Nobukawa B, Giardiello FM, Hamilton SR, Wu TT. Sporadic fundic gland polyps: common gastric polyps arising through activating mutations in the beta-catenin gene. Am J Pathol 2001;158:1005-10.

16. Stockinger A, Eger A, Wolf J, Beug H, Foisner R. E-cadherin regulates cell growth by modulating proliferation-dependent beta-catenin transcriptional activity. J Cell Biol 2001;154: 1185-96. 
17. Iwao K, Miyoshi Y, Nawa G, Yoshikawa H, Ochi T, Nakamura Y. Frequent beta-catenin abnormalities in bone and softtissue tumors. Jpn J Cancer Res 1999;90:205-9.

18. Park WS, Oh RR, Park JY, Lee SH, Shin MS, Kim YS, et al. Frequent somatic mutations of the beta-catenin gene in intestinal-type gastric cancer. Cancer Res 1999;59:4257-60.

19. Aust DE, Terdiman JP, Willenbucher RF, Chew K, Ferrell L, Florendo C, et al. Altered distribution of beta-catenin, and its binding proteins E-cadherin and APC, in ulcerative colitisrelated colorectal cancers. Mod Pathol 2001;14:29-39.

20. Sparagana SP, Roach ES. Tuberous sclerosis complex. Curr Opin Neurol 2000;13:115-9.

21. Hyman MH, Whittemore VH. National Institutes of Health consensus conference: tuberous sclerosis complex. Arch Neurol 2000;57:662-5.

22. Au KS, Hebert AA, Roach ES, Northrup H. Complete inactivation of the TSC2 gene leads to formation of hamartomas. Am J Hum Genet 1999;65:1790-5.

23. Hizawa K, Iida M, Matsumoto T, Tominaga M, Hirota C, Yao $\mathrm{T}$, et al. Gastrointestinal involvement in tuberous sclerosis. Two case reports. J Clin Gastroenterol 1994;19:46-9.

24. Kim BK, Kim YI, Kim WH. Hamartomatous gastric polyposis in a patient with tuberous sclerosis. J Korean Med Sci 2000; 15:467-70.

25. Gould SR, Stewart JB, Temple LN. Rectal polyposis in tuberous sclerosis. J Ment Defic Res 1990;34:465-73.

26. Tahri N, Turki H, Turki M, Triki C, Jlidi R, Zahaf A, et al. Gastrointestinal polyposis in Bourneville's tuberous sclerosis: an involvement often overlooked [French]. Ann Gastroenterol Hepatol 1996;32:123-7.

27. Catania MG, Mischel PS, Vinters HV. Hamartin and tuberin interaction with the G2/M cyclin-dependent kinase CDK1 and its regulatory cyclins A and B. J Neuropathol Exp Neurol 2001;60:711-23.

28. Soucek T, Rosner M, Miloloza A, Kubista M, Cheadle JP, Sampson JR, et al. Tuberous sclerosis causing mutants of the TSC2 gene product affect proliferation and p27 expression. Oncogene 2001;20:4904-9.

29. Soucek T, Yeung RS, Hengstschlager M. Inactivation of the cyclin-dependent kinase inhibitor p27 upon loss of the tuberous sclerosis complex gene-2. Proc Natl Acad Sci U S A 1998;95:15653-8.

30. Henry KW, Yuan X, Koszewski NJ, Onda H, Kwiatkowski DJ, Noonan DJ. Tuberous sclerosis gene 2 product modulates transcription mediated by steroid hormone receptor family members. J Biol Chem 1998;273:20535-9.

31. Lamb RF, Roy C, Diefenbach TJ, Vinters HV, Johnson MW Jay DG, et al. The TSC1 tumour suppressor hamartin regulates cell adhesion through ERM proteins and the GTPase Rho. Nat Cell Biol 2000;2:281-7.

32. Kanemasa H, Ozawa H, Konishi H, Ito T, Nishi M, Mitsufuji S, et al. Distribution of glucocorticoid receptor immunoreactivity in gastric mucosa of normal and adrenalectomized rats. Dig Dis Sci 1999;44:2081-7.

33. Fukuda T, Kobayashi T, Momose S, Yasui H, Hino O. Distribution of Tsc1 protein detected by immunohistochemistry in various normal rat tissues and the renal carcinomas of Eker rat: detection of limited colocalization with Tsc1 and Tsc2 gene products in vivo. Lab Invest 2000;80:1347-59.
34. So JB, Samarasinge K, Raju GC, Moochhala SM, Ti TK. Expression of cell-cycle regulators p27 and cyclin E correlates with survival in gastric carcinoma patients. J Surg Res 2000; 94:56-60.

35. Wei JJ, Li P, Chiriboga L, Mizuguchi M, Yee H, Miller DC, et al. Tuberous sclerosis in a 19-week fetus: immunohistochemical and molecular study of hamartin and tuberin [abstract]. Mod Pathol 2002;15:148A.

36. Mizuguchi M, Kato M, Yamanouchi H, Ikeda K, Takashima S. Loss of tuberin from cerebral tissues with tuberous sclerosis and astrocytoma. Ann Neurol 1996;40:941-4.

37. Mizuguchi M, Kato M, Yamanouchi H, Ikeda K, Takashima S. Tuberin immunohistochemistry in brain, kidneys and heart with or without tuberous sclerosis. Acta Neuropathol 1997; 94:525-31.

38. Mizuguchi M, Ikeda K, Takashima S. Simultaneous loss of hamartin and tuberin from the cerebrum, kidney and heart with tuberous sclerosis. Acta Neuropathol 2000;99:503-10.

39. Catania MG, Johnson MW, Liau LM, Kremen TJ, deVellis JS, Vinters HV. Hamartin expression and interaction with tuberin in tumor cell lines and primary cultures. J Neurosci Res 2001;63:276-83.

40. van Slegtenhorst M, Nellist M, Nagelkerken B, Cheadle J, Snell R, van den Ouweland A, et al. Interaction between hamartin and tuberin, the TSC1 and TSC2 gene products. Hum Mol Genet 1998;7:1053-7.

41. Plank TL, Yeung RS, Henske EP. Hamartin, the product of the tuberous sclerosis 1 (TSC1) gene, interacts with tuberin and appears to be localized to cytoplasmic vesicles. Cancer Res 1998;58:4766-70.

42. Nellist M, van Slegtenhorst MA, Goedbloed M, van den Ouweland AM, Halley DJ, van der Sluijs P. Characterization of the cytosolic tuberin-hamartin complex. Tuberin is a cytosolic chaperone for hamartin. J Biol Chem 1999;274:3564752.

43. Aicher LD, Campbell JS, Yeung RS. Tuberin phosphorylation regulates its interaction with hamartin. Two proteins involved in tuberous sčerosis. J Biol Chem 2001;276:21017-21.

44. Potter CJ, Huang H, Xu T. Drosophila Tscl functions with Tsc2 to antagonize insulin signaling in regulating cell growth, cell proliferation, and organ size. Cell 2001;105:35768.

45. Tapon N, Ito N, Dickson BJ, Hariharan IK. The Drosophila tuberous sclerosis complex gene homologs restrict cell growth and cell proliferation. Cell 2001;105:345-55.

46. Tsuchiya H, Orimoto K, Kobayashi K, Hino O. Presence of -potent transcriptional activation domains in the predisposing tuberous sclerosis (Tsc2) gene product of the Eker rat model. Cancer Res 1996;56:429-33.

47. Xiao GH, Shoarinejad F, Jin F, Golemis EA, Yeung RS. The tuberous sclerosis 2 gene product functions as a rab5a GTPase activating protein (GAP) in modulating endocytosis. J Biol Chem 1997;272:6097-100.

48. Bandyopadhyay U, Bhattacharyya DK, Chatterjee R, Chakraborty T, Banerjee RK. Effect of dexamethasone on the peptic activity of gastric lumen and mucosa. Biochem Pharmacol 1993;45:879-83. 